\section{EC hankers after more Framework research spending}

\begin{abstract}
Strasbourg. Increased spending on research and development in Europe won general approval at last week's summit meeting in Copenhagen, which marked the end of Denmark's six-month presidency of the European Communities (EC). This view, prompted by a paper on economic renewal in the EC by the European Commission's president, Jacques Delors, has now been echoed by the European Parliament.
\end{abstract}

A central feature of the Delors plan is that the EC should invest ECU5 billion (US\$6.1 billion) a year on a European information infrastructure. The document, commissioned by the member governments, says that an efficient decentralized economy requires a sound system of information highways and that the system should be continuously developed and updated, at an estimated cost of ECU5-ECU8 billion a year.

Member states have until 1 September to comment on the plan, so that a final document can be discussed by finance ministers under the chairmanship of Belgium, which now assumes the presidency of the EC. Decisions could then be taken at the next Community summit in December.

Danish prime minister Poul Nyrup Rasmussen, reporting to the European Parliament immediately after the summit, said that heads of state had responded positively to the Delors plan, which also urged member states to raise spending on research, development and innovation from 2 per cent of gross national product to 3 per cent.

Research was already on the agenda in Strasbourg, where the members of the European Parliament (MEPs) have been debating the plan to spend ECU18.4 billion on the 1994-98 Fourth Framework Programme. Pending ratification of the Maastricht Treaty (which gives the parliament more influence on EC research policy), members complained that the EC's commitment to research still falls short of the target of 6 per cent of their budget, agreed as long ago as 1985 .

Indeed, Rolf Linkohl (Social Democrat, Germany), who is rapporteur of the Energy, Research and Technology Committee, claimed that the proportion of the EC budget to be spent in the new framework programme is a reduction from 4 to 3.9 per cent.

The parliament also renewed its demand that renewable forms of energy should have the same priority as thermonuclear research, with more research on the environmental impact of waste disposal. Last week, it also endorsed a draft directive that, within ten years, 90 per cent of the 50 million tonnes of packaging waste produced in the $\mathrm{EC}$ each year will be recycled or incinerated to produce energy, a proposal unlikely to be backed by the Council of Ministers. Arthur Rogers

\section{Indian libraries pool science journal subscriptions}

New Delhi. Universities and research laboratories in India, forced by lack of funds to cut out subscriptions to foreign journals, are now networking their science libraries.

Under this scheme, no two libraries will import the same periodical, and all journals will be pooled. A scientist who cannot find the journal he wants on his own campus can get a photocopy of any article he needs from another library in the network.

Researchers complain that shrinking libraries are slowing down their work. The number of foreign journal subscriptions at Indian science libraries has fallen from nearly 22,000 in 1983 to 9,500 as a result of budget cuts, increased prices and erosion of the value of the rupee.

For example, the Indian Institute of Science in Bangalore and the Tata Institute of Fundamental Research in Bombay have reduced their subscriptions by a third and the Indian Institute of Technology (IIT) in New Delhi has dropped half the foreign journals on its subscription list. The situation is even worse in universities and in the 40 laboratories of the Council of Scientific and Industrial Research, which says it has funds only to pay salaries.

"Resource sharing through computer interconnection is the only way to cope with the information drought in academic and research institutions", says Dr T. Viswanathan, director of the Indian $\mathrm{Na}$ tional Scientific Documentation Centre (INSDOC), which is leading the network movement. The first network, which started libraries. They exchange the contents pages of periodicals, and scientists order the articles they want electronically. A courier service run by the network centre delivers a photocopy within 48 hours.

"By paying only a $\$ 7,000$ annual membership fee, a library has access to all the foreign journals collectively subscribed to by all the network members", says last month in Madras, already connects ten
Viswanathan. The libraries save about $\$ 200,000$ a year by not duplicating subscriptions. According to Viswanathan, all the 60 science libraries in and around Madras will have joined the network in the next few months. In Delhi, 28 libraries have formed a network and have saved $\$ 170,000$ by pooling journals. Similar networks are being set up in Bangalore and Calcutta.

Researchers whose libraries do not belong to a network are being encouraged to subscribe to INSDOC's Contents Abstracts and Photocopying Service (CAPS). For a nominal fee, subscribers receive every month the contents pages of up to 40 journals of their choice by fax or e-mail, and can then order abstracts or complete articles. INSDOC's own library can service 20 per cent of requests. "If we don't have the journal, we get it from a library that has", says Viswanathan.

INSDOC has regional offices in Calcutta, Bangalore and Madras, and a van makes a daily round of local libraries to pick up journals and photocopy the articles on the spot. "If the subscriber is in Delhi and the journal is also in Delhi, the photocopy will be hand-delivered within 48 hours", says Viswanathan. "Otherwise it will take up to a month." INSDOC has links with 800 science libraries and has access to every foreign science journal imported into India.

According to Viswanathan, most CAPS users are university and industrial scientists, and more than half the requests are for articles in medicine, the life sciences and engineering, most of them from Nature.

But most scientists in India believe that the problems caused by lack of access to journals can be only partly solved by networking and CAPS. "Networking of national science libraries will take time", says Mohinder Singh, chief librarian of IIT. "This cannot immediately make up for the steep fall in the acquisition of journals and books."

K. S. Jayaraman

\section{Science network for Europe}

Munich. Science information officers representing national science councils and major research institutes of ten European countries have organized a communication network to exchange information on science and science policy. Known as ESCIN (European Science Communication and Information Network), the group plans to publish a European handbook of scientific organizations this year, and is negotiating the start-up of a European-wide newsletter.

Communication in Europe is patchy. Countries tend to be unaware of major national scientific events and specific national laws affecting the practice of scientists in other countries. Founder member Hein Meijers, from the Netherlands Organization for Scientific Research (NWO), says that there has for a while been a strong feeling that scientists needed to communicate between themselves "at a non-political level". ESCIN is hoping for financial support from the European Communities.

Alison Abbott 